\title{
Systemic Risk and the Pursuit of Efficiency
}

Kartik B. Athreya

$\mathrm{W}$ hat is systemic risk? When might it arise? How should it influence policymakers? In this essay we identify systemic risk with the presence of linkages between market participants whereby problems for one directly create problems for others. We argue that such situations can arise from the use of contractual arrangements, especially debt that requires frequent refinancing and liquidation in the event of an inability to repay. The presence of spillover effects can, in turn, lead to outcomes in the wake of shocks that can be unambiguously improved via policy intervention. Nonetheless, we caution against taking this as a license to intervene after the fact, and instead suggest that observed contracting arrangements may be important in promoting efficient trade between parties from a "before the shock" perspective. We argue that helping to ensure efficiency as seen prior to a shock is the right goal for policymakers. Lastly, we note that the pursuit of such an objective may require credible commitments to tolerating inefficiency after a shock.

In the past two years, U.S. financial markets have undergone dramatic changes, with storied firms vanishing from existence and others surviving only as a direct result of public sector intervention. A handful of these events stand out as emblematic. These are, respectively, the bailouts of Bear Stearns, AIG, and the housing government-sponsored enterprises; the institution of large credit programs such as the Term Asset-Backed Securities Loan Facility (TALF) and the Troubled Asset Relief Program (TARP); and the striking nonbailout of Lehman Broth-

- The author is a senior economist at the Federal Reserve Bank of Richmond. He would like to thank Huberto Ennis, Amanda L. Kramer, Devin Reilly, Aaron Steelman, John Walter, John Weinberg, and Alex Wolman for discussions and detailed comments and Sam Henly for able research assistance. The views expressed are those of the author and not necessarily those of the Federal Reserve System.

DOI: http://doi.org/10.21144/eq1010103 
ers. A common thread in the interventions that took place, and the criticism of the one that did not, was the appeal to the idea that the failure of one financial institution would threaten the health of others and, as a result, hurt the ability of the financial system as a whole to channel resources to productive investment projects. In a 2008 assessment of the TARP program, for instance, then-Treasury Secretary Henry Paulson argued: ${ }^{1}$

"The crisis in our financial system had already spilled over into our economy and hurt it. It will take a while to get lending going and repair our financial system, which is essential to an economic recovery. This won't happen as fast as any of us would like, but it will happen much, much faster than it would have had we not used the TARP to stabilize our system. Put differently, if Congress had not given us the authority for TARP and the Capital Purchase Program and our financial system had continued to shut down, our economic situation would be far worse today."

Similarly, the rescue of Bear Stearns was justified by the thenpresident of the New York Fed, Timothy Geithner, as follows:

"We judged that a sudden, disorderly failure of Bear would have brought with it unpredictable but severe consequences for the functioning of the broader financial system and the broader economy." ${ }^{2}$

\section{DEFINING SYSTEMIC RISK}

Aside from policymakers, economists have tried to understand the potential for spillovers both within the financial sector, as well as those that might flow from the financial sector to the nonfinancial (or "real") sector of the economy. Research in this area captures the idea of destructive spillovers with the term "systemic risk." A consensus view of systemic risk comes from Acharya et al. ${ }^{3}$ who define it as "... the risk of a crisis in the financial sector and its spillover to the economy at large." De Bandt and Hartmann ${ }^{4}$ use the related term "systemic crisis" to capture "... a systemic event that affects a considerable number of financial institutions or markets in a strong sense, thereby severely impairing the general well-functioning (of an important part) of the financial system. The well-functioning of the financial system relates to the effectiveness and efficiency with which savings are channeled into

\footnotetext{
${ }^{1}$ Prepared remarks by Paulson before the House Financial Services Committee, November 18, 2008.

${ }^{2}$ New York Times, April 8, 2008.

${ }^{3}$ Acharyaet al. (2009).

${ }^{4}$ de Bandt and Hartmann (2000).
} 
the real investments promising the highest returns. For example, a systemic financial crisis can lead to extreme credit rationing of the real sector ('credit crunch')."

In what follows, we will discuss the notion of systemic risk, describe recent economic theory related to the idea, and suggest some implications that these ideas have for policymakers. In terms of emphasis, we make no attempt to be exhaustive and will focus primarily on conceptual issues surrounding systemic risk and policymakers' role in not only its mitigation, but also its very presence. ${ }^{5}$

Economists have categorized two broad sources of systemic risk: externalities and implicit guarantees. Externalities, loosely speaking, are effects that occur when one party's actions affect another's either by markedly affecting prices or by directly limiting the options available to another in any other way. Such direct effects should be contrasted with the indirect effects that occur in settings where individual participants face prices that they regard as too small to influence.

As for implicit guarantees as a source of systemic risk, the idea is this: Any belief among financial market participants, especially creditors, that they will be made whole by the public in the event of the failure of the assets they finance (i.e., that they will be "bailed out") will lead them, all else equal, to (i) take greater risks, even if that means becoming ever more opaque or interconnected, and (ii) grow too large. Externalities and implicit guarantees are related. The existence of the latter allows market participants to structure operations in ways that create externalities (for example, by growing very large via leverage), thereby virtually guaranteeing themselves a bailout from a benevolent government intent on avoiding the collateral damage created by these externalities.

The discussion of systemic risk thus far suggests that it describes situations in which markets are unable to appropriately allocate resources after the occurrence of a surprise event or "shock." So we might begin by asking: What is meant by "appropriate"? One attribute economists often look for in outcomes is Pareto efficiency. A Pareto-efficient outcome is a feasible outcome such that no one can be made better off without hurting someone else. Outcomes that are not Pareto efficient are therefore clearly wasteful. We define systemic risk as the risk that trading arrangements will not yield Pareto-efficient outcomes, particularly in the wake of a shock to the system.

\footnotetext{
${ }^{5}$ For those interested in more detailed surveys of systemic risk, de Bandt and Hartmann is useful, and for autopsies of the recent crisis, the received literature now provides many options, but two especially useful treatments are the symposium issue (Winter 2009) of the Journal of Economic Perspectives and the book-length treatment of Acharya and Richardson (2009).
} 
The preceding implies that in settings where shocks, such as the sudden revaluation of real estate, can occur, one can differentiate between the Pareto efficiency of a trading arrangement after, and before, the realization of the shock. If the expected welfare of participants prior to the realization of shocks cannot be improved, the outcome is said to be ex-ante Pareto efficient. And if no Pareto improvements can be made after the shock, we have an ex-post Pareto-efficient outcome. A fact for the reader to keep in mind is this: There are outcomes that are ex-post Pareto efficient that are not ex-ante efficient. In particular, a commitment by policymakers to ensure ex-post efficiency can actually prevent a society from attaining the ex-ante efficient deployment of its resources. In this essay, we will argue that the goal of policy should be to approximate ex-ante efficiency.

The main sphere of policymaking we address is that of regulating financial markets. Financial markets facilitate the transfer of funds between parties at various times and under various contingencies. A question to address, then, is how effective are these markets at achieving efficient outcomes?

Assessing the extent to which a financial system is allowing society to attain an ex-ante Pareto-efficient allocation is not an easy task, but there are guidelines. Households use financial instruments to hedge risks, prepare for retirement, and buy homes, among other things. Financial markets therefore mainly assist households in maintaining a stable lifestyle. Perhaps naturally, then, an observable hallmark of a well-functioning financial system for households is one where expenditures usually do not move suddenly unless there has been an unexpected event suffered simultaneously by a significant group of households, such as occurs in a recession. By this measure, a consensus view of research on this topic is that U.S. households are able to fairly effectively, but not perfectly, "smooth" their consumption against all but those shocks that simultaneously affect significant proportions of households, or those that are extremely long-lasting, such as disability or displacement. In particular, household consumption is shielded well from temporary shocks, ${ }^{6}$ most households arrive well-prepared for retirement, ${ }^{7}$ and consumption inequality among those with similar expected lifetime earnings does not grow substantially with age. ${ }^{8}$

Firms are, of course, the other major user of financial instruments, borrowing directly from households via capital markets, borrowing from banks, arranging trade credit with one another, and hedging risks

\footnotetext{
${ }^{6}$ Blundell, Pistaferri, and Preston (2008).

${ }^{7}$ Aguiar and Hurst (2005) and Scholz, Seshadri, and Khitratakun (2006).

${ }^{8}$ Heathcote, Storesletten, and Violante (2005).
} 
through options, swaps, and other types of instruments. Unfortunately, unlike the case of households, detecting how effective financial markets are at efficiently allocating funds across producers is not straightforward. Theoretical work does not give definitive tests of financial market inefficiency. ${ }^{9}$ As a result, policymakers have been forced to rely largely on more heuristic methods to assess strain or illiquidity in financial markets. Specifically, the sharp changes in observed interest rate spreads and credit volumes in many short-term debt markets starting in mid2007 led to the conclusion among many policymakers that such data reflected inefficiency. The data on interbank lending spreads ${ }^{10}$ were seen as deviations from fundamentals suggestive of severe impediments to trade arising from counterparty risk and asymmetric information. As a result, policymakers, especially those within the Federal Reserve, focused most of their efforts on ensuring that a wide spectrum of firms was able to access short-term finance.

\section{WHAT DOES ECONOMICS TELL US ABOUT SYSTEMIC RISK?}

Of specific concern to us here is the systemic risk that propagates difficulties in one financial sector firm to other financial sector firms, and then, possibly, to the nonfinancial sector as well. The importance of the spread of spillovers between firms suggests that systemic risk is, at its heart, a product of the linkages that exist both between firms and between households and firms. In what follows, we detail some of the central lessons of economic theory and explain how they help us think about these linkages and view policies aimed at improving outcomes.

\section{Lesson 1: Mere Linkages between Economic Participants Do Not Imply Inefficiency}

Economics is interesting because of linkages. Put another way, resource allocation is relevant only because most goods and services we value have the property that what one party consumes precludes the use of these resources at a later date or by others. When a firm places an order for more plastic to make children's toys, for example, it necessarily becomes unavailable for making life-saving syringes for medical use. Does this mean that "too many" toys will be produced relative to syringes? The answer is: It depends on the cost perceived by users of both items. The most important achievement of 20th century eco-

\footnotetext{
${ }^{9}$ See, e.g., deBandt and Hartmann (2000).

${ }^{10}$ See, e.g., Cecchetti (2009).
} 
nomics was to show that, in general, there is a system of prices for all goods and services such that if self-interested traders cannot manipulate them, then (i) these prices will allow all participants in the economy to feasibly buy and sell what is best for them, and (ii) that the single-minded pursuit of self-interest subject only to the constraints imposed by these prices actually leads to a Pareto-efficient outcome. ${ }^{11}$ This result is the so-called "Invisible Hand" theorem and was famously first conjectured by Adam Smith. Therefore, in the context of our example, the answer depends on whether markets exist for both items and, if so, whether all participants take the prices in these markets as given (i.e., not up for haggling). Otherwise, there is no guarantee of efficiency. The Invisible Hand theorem is very general and fully applies to settings involving trade in financial instruments.

The Invisible Hand result teaches us that inefficiency stems fundamentally from the ways in which the competing interests of trading partners are adjudicated. ${ }^{12}$ In markets for goods and services, this is generally done by allowing competitive processes to work in the hope that they will generate prices that all participants take as given. ${ }^{13}$ However, as we will argue, in financial markets, especially banking, trading arrangements that allow parties to attain ex-ante efficiency can sometimes create the possibility of instability. As a result, financial contracting arrangements can in some instances create situations where productive interventions by policymakers exist. For example, the extreme flexibility of "demandable deposit" contracts offered by banks allows households to invest efficiently in productive long-term projects while simultaneously insuring themselves against the risk of sudden liquidity needs. Nonetheless, as we will discuss below, such contracts can also allow for self-fulfilling and destructive runs on banks. In turn, the institution of deposit insurance can help rule out such events, and thereby push outcomes toward ex-ante Pareto efficiency.

\footnotetext{
${ }^{11}$ See, e.g., Debreu (1959).

12 To repeat, in any setting with limited resources, what one party does must affect all others. The only question then is how these effects manifest themselves. The Invisible Hand result tells us that when there are markets for all relevant goods and services, the interaction of parties in settings where they cannot affect prices through their individual actions leads to Pareto-efficient outcomes.

${ }^{13}$ Think of the auctions for commodities that occur routinely: Millions of small buyers and sellers individually can do essentially nothing but accept the price coming from the auction house, but together their actions certainly affect the price that is set.
} 


\section{Lesson 2: Spillovers Cause Inefficient Responses to Shocks}

When linkages are not mediated through prices that are taken as given, the failure of a specific financial intermediary may impose costs on unrelated third parties and may use up scarce resources. It is clear that if a heavily interconnected firm is not allowed to operate after it becomes delinquent on its liabilities, severe disruptions may occur elsewhere. This is simply because it may take time and resources for the physical, organizational, and human capital at that entity to be redeployed. Thus, failure itself can lead to costs and ex-post inefficiency that, given a choice, policymakers will opt to avoid, all else equal. Consider next the costs of forcing a failed entity into bankruptcy. Taken in isolation, note first that the liquidation of a firm via formal bankruptcy will typically be beneficial relative to the status quo. Bankruptcy courts, after all, exist primarily to ensure efficient liquidation, i.e., to decide how best to reorganize an entity that is unable to meet commitments to creditors, dissolving it (ideally) in only those instances when its "going concern" value is low and, in these instances, trying precisely to prevent inefficient liquidation processes. As a result, such procedures help society channel resources to their most productive users.

However, the specter of spillovers grows with the size and, in some cases, the number of distressed institutions. In practice, such a view was expressed to justify the extremely large bailout of AIG, for example. The fear was that the shuttering of such a large or "interconnected" firm would then sow the seeds of further distress. ${ }^{14}$ In other recent cases, the specific fears have been that the liquidation of a firm's assets, especially when large, would lower asset prices overall and cause further problems. Specifically, a fall in asset prices was seen to have the potential to lead to a further round of tightening in credit availability for unrelated firms by lowering their ability to post collateral. ${ }^{15}$ Thus, bankruptcy courts, though set up to aid efficiency, may take actions that create externalities.

\footnotetext{
14 "The U.S. Department of the Treasury (Treasury), the Federal Reserve Board, and the Federal Reserve Bank of New York agreed that the collapse of AIG could cause large and unpredictable global losses with systemic consequences." Prepared testimony of Timothy Geithner, March 24, 2009.

${ }^{15}$ Criticisms of the nonbailout of Lehman Brothers usually have taken this view.
} 


\section{Lesson 3: The Sources of Spillovers Vary Substantially}

Presently, there are several types of linkages that researchers have identified that can forcefully transmit ex-post inefficient outcomes in financial markets into production and the "real" side of the economy.

First, given the centrality of banks and bank-like institutions in the recent crisis, it is useful to review briefly the most influential model of banks available: that of Diamond and Dybvig. ${ }^{16}$ In their account of banks, the authors envision a scenario in which a very large number of households have funds and would like to save for the future, but are faced with random shocks to their spending needs. The shocks represent any event that forces the household to withdraw its deposit. For example, a household may need to make an emergency repair to its home or car or face a large out-of-pocket medical or legal expense. Given this uncertainty, households will value a savings instrument that can be easily liquidated if need be.

Diamond and Dybvig's scenario is one in which households' shocks are independent of each other, in the sense that one person's receipt of a shock doesn't imply that others have received one as well. As a result, the fact that there are a large number of households guarantees that the proportion of those that will realize the shock is known with certainty. ${ }^{17}$

Consider now a situation where the investment projects available in the economy all have a lengthy gestation period - if liquidated early, they generate low returns. Think of office buildings, or airplanes, or homes: Each takes time and each, if half-completed, is still nearly worthless. This creates a problem: While it would be nice to be able to take advantage of these projects, few individuals would risk having their funds tied up without recourse. So is there a way for society to fund these projects while protecting investors/depositors?

Since the shocks to households imagined by Diamond and Dybvig are independent, a financial intermediary that can collect funds from many households will be able to (i) hold funds in reserve for only the proportion it knows will need to withdraw funds due to a shock and (ii) use the remaining funds to make productive long-term investments. This is precisely what Diamond and Dybvig call a bank. The lesson, at this point, is that the ubiquitous institution of a bank allows for

\footnotetext{
${ }^{16}$ Diamond and Dybvig (1983).

17 Think, for example, of a large number of individuals, where each person holds an unbiased coin. If they all flip their coins, we cannot know the outcome for any one individual with certainty beforehand, but we do know that the fraction of people who flip "heads" (or "tails") will nearly always be very close to one-half.
} 
productive investments, but does so in large part by forfeiting all flexibility in its obligations to depositors.

Unfortunately, the absence of flexibility noted above can create a new problem. And this is the other remarkable feature of Diamond and Dybvig's analysis: It captures bank runs, a central feature of banking prior to deposit insurance. In particular, there is nothing in the account of Diamond and Dybvig to rule out individuals believing that a bank lacks sufficient funds to meet all withdrawal needs. If investors believe this, and the bank redeems deposits on a first-come, first-served basis, households may choose to run the bank. Given the fact that the bank held only a fraction of all deposited funds in reserve and invested the rest, a run will necessarily force the bank to liquidate at least some of its long-term investments to meet redemption requests, and society will lose as a result.

The introduction of deposit insurance can rule out such self-fulfilling "crises of confidence." But, once again, this insurance is not without other, less desirable, side effects. In particular, deposit insurance changes both the incentives and ability of bank management and ownership to take risks. First, when publicly provided, deposit insurance removes incentives for the bank's creditors (insured depositors) to ask what the bank is doing with their money. Second, even when deposit insurance is privately run, the incentives of equity holders to take risks grow as bank capital deteriorates: Big gambles can have large payoffs for both owners and a management that has little left to lose. Notice that in this instance, corporate governance is not the issue; the firm is being operated in the best interests of shareholders. It is just that their interests no longer necessarily coincide with societally desirable goals. In such situations, the shareholders themselves may urge the manager of the firm to take risks, including those that generate interconnections and thereby foster spillovers.

As a result of the lack of equity holders' incentives to limit risktaking in bad times and insured depositors' perpetual indifference to bank asset quality, providers of insurance, and regulators in the case of FDIC-insured banks, are left with the task of monitoring bank activities. They must ensure that huge investments in generally unproductive projects are not pursued simply because they might pay off in an unlikely event. In the absence of such oversight, bank investments would almost certainly be allocated inefficiently from the ex-ante perspective and virtually ensure deadweight costs if liquidated.

The incentives to take large gambles create yet another problem. Deadweight costs of the sort we mentioned earlier will likely be most important in cases where the institution being liquidated is large. As a result, if policymakers are very concerned with limiting ex-post 
deadweight losses, they will feel pressure not to allow such liquidation and instead may transfer public resources to the failing institution. The crucial problem with this, as alluded to at the outset, is that such pressure will be anticipated by banks themselves and lead them, all else equal, to grow too big. This is the classic "too big to fail" (TBTF) problem. ${ }^{18}$

Another potential source of spillovers arises from the absence in some markets of trading institutions capable of tracking net claims rather than gross claims. The main idea is this: Consider a setting with three firms, A, B, and C. Firm A owes Firm B $\$ 100$, while Firm B owes Firm C $\$ 100$. Clearly, if netting was possible, only one transaction needs to occur: Firm A pays Firm C. But in a setting in which gross claims must be settled, more transactions must occur. In addition, if either Firm A or B must make an asset sale in order to raise the $\$ 100$ it owes, problems may occur. In the midst of widespread suspicion on asset quality, it may be unable to get a price reflective of the true underlying quality of the assets being sold; and if the sale is made anyway, the net worth of both institutions can decline. This idea has received formal attention from economists. The classic contribution that highlights the potential for wasteful liquidation and allocation is that of Kiyotaki and Moore ${ }^{19}$ in which chains of inefficient liquidation can occur due to a failure of either centralized netting of contracts or the availability of a single "deep-pocketed" creditor. In such an environment, a single default can lead to a "spiral" of liquidation that significantly amplifies an initial shock. Such risk is likely to be most relevant when many investors face risk arising from default by their counterparties, and in so-called over-the-counter (OTC) markets there was very little information that was centralized and thereby known to a party that could monitor the ability of obligors to make good on promises. By contrast, a centralized exchange may have been able to keep much better track of net obligations, and thereby avoid default. Shleifer and Vishny ${ }^{20}$ focus on the issue that there may be only a limited number of parties with the expertise to value and manage certain kinds of assets.

The absence of netting is likely to be most problematic when the seller of assets is a bank or other relatively opaque institution. In

\footnotetext{
18 See, e.g., Stern and Feldman (2004). At banks with access to insured deposits, the competitive pressure to continue acquiring exposure to high-risk mortgages was likely to have been substantial. Chuck Prince, CEO of Citigroup, famously stated that "... as long as the music is playing, you've got to get up and dance. We're still dancing." Financial Times, July 10, 2007.

${ }^{19}$ Kiyotaki and Moore (1997).

20 Shleifer and Vishny (1992).
} 
particular, a traditional view of banks is that they are entities that specialize in "information intensive" lending. As a result, banks typically fund precisely those investment projects that are not sufficiently transparent or standardized to permit the use of capital markets. As a result, few are in a position to value such assets when they are sold, and this possibility in turn may generate what economists call a "Lemons problem." That is, if the quality of an asset is known to sellers but not to buyers, and if sellers anticipate a low price, then the quality of the assets placed for sale will be disproportionately low (i.e., "Lemons"). In the absence of a credible mechanism to discern quality, asset prices may be inefficiently low in the sense that there may be buyers willing to pay high prices for high-quality assets but find them unavailable. Therefore, while a large liquidation may be sufficient to induce inefficiency, it is not necessary.

At a general level, Lemons problems seem likely to have played an important role in explaining why the initial wave of mortgage defaults led to greater than 10 percent unemployment rates. A very rough summary of recent events might be the following: Mortgages defaulted and securitization led the exposure to these defaults to be very widespread and difficult to assess. Many who invested in these assets did so by borrowing short-term. When the performance of mortgages eroded, these investors were asked by their creditors to lower their leverage to increase the likelihood of repayment. This often necessitated the sale of assets. To the extent that sellers were seen to know more than buyers about what they were selling, the price commanded by these assets was low-reflecting the possibility that the seller was intent on unloading his worst assets on unwitting buyers. As some sold at these low prices, others were directly affected in their ability to sell assets. In the interim, some investors, e.g., so-called structured investment vehicles (SIVs) and conduits, had arranged for backup lines of credit from banks. As banks made good on these commitments, their health and corresponding ability to fund projects, including those completely unrelated to mortgage lending, were undercut. As a result, what started as a crisis on "Wall Street" became a larger crisis on "Main Street."

The preceding description of a "death spiral" has been formalized to account for some additional specifics of the current crisis. Most recently, Brunnermeier ${ }^{21}$ emphasizes two spirals related to forces identified in Kiyotaki and Moore: (i) a "loss" spiral and (ii) a "margin" spiral. In the former case, a reduction in asset prices (possibly for entirely fundamental reasons) lowers the ability of participants to borrow,

${ }^{21}$ Brunnermeier (2009). 
especially leveraged ones. This is because the fall in asset prices lowers the net worth of the leveraged entity by much more than the gross worth, and it is net worth that matters for being able to post collateral and, in turn, borrow. Subsequently, the loss in net worth may necessitate the sale of more assets, as lenders will not want exposure to such a leveraged borrower to persist. Such pressure will lead the borrower to sell some of his assets to restore the original leverage ratio, which further lowers the net worth of other agents, and soon. A margin spiral is one where the loss spiral is made worse because lenders may no longer be content with allowing the same leverage ratio and, by demanding lower leverage, force greater asset sales by each constrained institution, further pressuring asset prices downward.

The prevalence of OTC transactions for many derivatives, especially credit-default swaps, later proved to be a source of significant counterparty risk. In turn, the failure of an insurer to deliver as promised may itself threaten the health of those who purchased the insurance and may force them to liquidate positions to meet obligations. Such liquidations can, as before, lead to downward spirals. The case of AIG illustrates this clearly. Many holders of mortgage-backed securities purchased insurance against a loss in their value. AIG collected premiums in return for promising to buy back these securities at face value in the event of default. However, it later turned out that the firm would be incapable of making the promised payments, and its unanticipated failure could reasonably be associated with some of the inefficiency-inducing spirals discussed above.

An issue related to margin spirals and asset sales is that of the valuation of a firm's balance sheet. The practice of generating a real-time valuation of the balance sheet goes by the terms "fair value accounting" (FVA) and "mark-to-market" accounting. After the savings and loan (S\&L) crisis of the 1980s, regulators and policymakers came to realize that when an insured depository institution is aware that its balance sheet has deteriorated, but regulators aren't, very bad things can happen. In particular, poorly performing insured depository institutions can raise funds by offering high interest rates on deposits and other short-term funding and use the proceeds to invest in projects that pay off handsomely in rare cases, but most often do not. Commercial real estate, in particular, was a favorite for speculative investments by S\&Ls.

As a result, many financial institutions now are asked to routinely present valuations of the objects on their balance sheets (the assets, in particular). These valuations are really a thought experiment in which the firm assesses the value of assets were they to be sold immediately. In settings in which trading arrangements (i.e., markets) allow for the 
easy sale of assets without suspicion of them being Lemons, FVA will keep insolvent institutions from raising funds to invest in bad projects. However, in cases where asset markets are afflicted by serious Lemons problems, an institution may be inaccurately portrayed as undercapitalized, in which case it must either sell assets to repay creditors (in other words, shrink its balance sheet) or issue new equity. Both of these options may cause further problems, the former for reasons we have already discussed and the latter because the very issuance of new equity might be perceived as a signal that an entity is undercapitalized. Thus, it is possible that some of the spillovers that occurred came from measures designed to prevent them from occurring in the first place. institutions can decline. This idea has received formal attention from economists. The classic contribution that highlights the potential for wasteful liquidation and allocation is that of Kiyotaki and Moore, in which chains of inefficient liquidation can occur due to a failure of either centralized netting of contracts or the availability of a single "deep-pocketed" creditor. In such an environment, a single default can lead to a "spiral" of liquidation that significantly amplifies an initial shock. Such risk is likely to be most relevant when many investors face risk arising from default by their counterparties, and in so-called over-the-counter (OTC) markets there was very little information that was centralized and thereby known to a party that could monitor the ability of obligors to make good on promises. By contrast, a centralized exchange may have been able to keep much better track of net obligations, and thereby avoid default. Shleifer and Vishny focus on the issue that there may be only a limited number of parties with the expertise to value and manage certain kinds of assets.

We have argued that spillovers leading to ex-post inefficiency can come from many places, of which we named a few: (i) demand-depositstyle contracts, (ii) distorted incentives created by deposit insurance and financial institution size, (iii) the absence of centralized netting of contracts, especially in derivatives, and (iv) regulatory practices. It should be clear, therefore, that there are widely varying, and individually coherent, arguments as to why systemic risk may be present. There will, in turn, usually be interventions that can genuinely improve outcomes, though typically from the ex-post perspective. This is an important point to keep in mind, and one that is not always appreciated by those advocating pure "laissez faire" approaches to crisis management. However, it is perhaps equally crucial to recognize that the promise of help from policymakers to avoid inefficiency ex post can (i) disrupt ex-ante efficient contracting arrangements and (ii) increase the odds of ending up in a situation where such intervention takes place. Therefore, it is important to understand first why certain risks may be 
an unavoidable side effect of contractual arrangements constructed to ensure ex-ante efficiency. In general, such an evaluation is best done on a case-by-case basis.

\section{Lesson 4: Many of the Linkages Leading to Fragility and Ex-Post Inefficiency Stem from Purposeful Choices}

The preceding section showed that trading arrangements in financial markets often leave intact features that can lead to inefficient responses to shocks, but that tolerating ex-post inefficiency may be essential to allowing for beneficial outcomes from an ex-ante perspective. The inflexibility of short-term debt in banking arrangements, for example, was shown to place burdens on the depository institutions, predisposing them to being run and to becoming a source of spillovers. Nonetheless, such arrangements are precisely what might allow society to invest in productive ventures.

A ubiquitous feature of the current crisis, and one that arguably sets it apart from previous periods of rapid asset-price appreciation, is the pervasive use of debt finance. Therefore, given its inflexibility - and demands for the liquidation of assets in the event of poor outcomeswhy is debt such a pervasive contractual form? An answer is suggested in a classic work of Townsend. ${ }^{22}$ In this paper, the author studies a setting in which a lender can generate a return on an investment only by hiring a worker, and where there turn on the investment can be observed only by paying a cost. The author then shows how a simple debt contract achieves ex-ante Pareto efficiency. That is, the optimal contract is one where borrowers make a constant repayment to lenders except in bankruptcy when they report an inability to pay as promised. In this case, the borrowers' output is verified and assets are seized and liquidated. No further opportunities to improve the well-being of both borrower and lender remain.

An important aspect of Townsend's analysis is that, in the cases where a borrower reports an inability to make the specified repayment, it doesn't help either party to use up resources that could instead be divided between them. Thus, a costly liquidation process may well be worse, ex post, than, say, partially forgiving the debt. But without this commitment to force the borrower into liquidation whenever he claimed that project returns were poor, the manager of the project would be able to report that the project always generated poor returns, repay

\footnotetext{
${ }^{22}$ Townsend (1979).
} 
very little, and retain the rest. Knowing this, the lender might never lend in the first place, putting a stop to a socially useful investment.

As discussed at the outset, recent calls for intervention by policymakers have uniformly appealed to the idea that inefficient outcomes would otherwise result. However, a lesson of the preceding discussion is that one can accept the idea that such inefficiency may result without intervention, while keeping in mind that the anticipation of such afterthe-fact interventions can damage the ability of market participants to effectively structure contracts.

\section{IMPLICATIONS FOR POLICYMAKERS}

Policymakers seem now to have recognized that the forces created by implicit guarantees and an unwillingness to tolerate ex-post inefficiency may be important and have reacted by proposing legislation. Most recently, legislation under consideration in the Senate seeks to substantially overhaul the regulation of financial institutions, largely with a view toward containing actions that will lead to systemic risk, through the creation of a systemic risk authority. ${ }^{23}$

The recent crisis, while beginning with household-level decisions to default on mortgages, has largely been a crisis of short-term funding for banks and nonfinancial firms. Given that neither financial intermediaries nor firms are people, the importance of protecting the incomes of such entities from sharp falls is not by itself a compelling rationale for policy intervention. The goal of policymakers in these instances, if anything, might be to ensure that the entities best equipped to channel funds to productive projects remain able to do so. Nonetheless, the discussion thus far has alluded to the idea that what market participants expect financial market policymakers and regulators to do ex post will matter for their decisions ex ante. Given this, there are some general implications for policymakers.

\section{Be Aware of Time Inconsistency}

Perhaps the single most important idea that economics has to offer the practice of policymaking is that of "time inconsistency." A policy is a rule that spells out what a policymaker will do under various contingencies now and in the future. A policy is said to be time inconsistent if a policymaker would opt in the future to not carry out the prescription of a previously announced policy wherever it was not optimal to do so

\footnotetext{
${ }^{23}$ See the U.S. Senate Committee on Banking, Housing, and Urban Affairs hearing titled "Establishing a Framework for Systemic Risk Regulation" held July 23, 2009.
} 
from that time forward. Instead, such a policymaker will choose new policies in the future by repeatedly reoptimizing. The downside to this is that he will not be able to credibly promise or threaten certain future actions, even when such a promise would allow for actions that would be clearly beneficial from the viewpoint of the present. Knowing this, individuals (i) will ignore the possibility that the strategy announced in the present will actually be implemented in certain eventualities, and, more detrimentally, (ii) can force the hand of the policymaker in the future by taking actions in the present.

The preceding is a bit abstract, so consider the classic example of time inconsistency from the seminal article of Kydland and Prescott, ${ }^{24}$ in which the idea was first formalized. Imagine a society where some of the land may flood frequently enough to make home construction a bad idea from the ex-ante perspective. Ideally, the right policy for the government in this instance would be to announce that it would not help those whose homes have flooded. If credible, this would prevent building on the floodplain and, in turn, void the need to bail out anyone after the flood. But, if a benevolent government lacks the commitment to refrain from helping to reconstruct the homes after a flood, private citizens will rationally expect that any homes that are built are indeed insured. As a result, homes will be built on floodplains and, since floods will occur, the government, if it is benevolent, will find itself helping homeowners after the fact. If the expected costs to society from not building there in the first place are smaller, society as a whole loses.

There are at least two lessons here. First, for policymakers, "tough talk," such as announcing that there will be no future bailouts, will, if not accompanied by something that makes the policy intentions credible, be disregarded at best. Second, there is a lesson for the broader public. In order to expect policymaking to meaningfully alter decisions, one must ask whether a policymaker has the willingness to stick to an announced policy, especially when the optimal choice in the future might be to let bygones be bygones.

\section{Pursue Ex-Ante, not Ex-Post, Pareto Efficiency}

Given the ability, and willingness, of policymakers to intervene to ensure efficiency in the wake of a shock, why is the pursuit, if not attainment, of ex-ante Pareto efficiency a useful standard for the regulators of financial institutions? In the context of financial markets, there are at

\footnotetext{
${ }^{24}$ Kydland and Prescott (1977).
} 
least three reasons. First, in markets where there is no informational advantage held by one party relative to another, and all parties can be forced to honor their promises, policies aimed at the achievement of ex-ante efficiency ensure ex-post efficiency; one needn't target the latter explicitly. Second, in the presence of informational advantages held by one party over another, or when parties cannot be presumed to do as promised, ex-post interventions, even when they ameliorate expost inefficiency, can undermine private contracts engineered to reflect a variety of considerations necessitated by the informational frictions present. For example, debt contracts were seen to be useful in helping parties attain financing even when one party faced the prospect of being cheated by the other. In turn, even well-meaning policies that hinder the seizure and liquidation of assets as per the contract could inhibit the financing of many worthy projects. Third, in a world of smart, forward-looking private sector decisionmakers, the willingness to pursue ex-post efficiency (or the inability to stop from pursuing it) can lead society to wasteful allocations of resources through misdirected investments, tax distortions, and deliberate exploitation of the taxpayer through excessive risk-taking. This is the lesson of the time inconsistency problem.

Recalling the case of AIG, we can see that once its inability to meet the claims of its creditors became clear, policymakers intervened, perhaps justifiably under an ex-post Pareto efficiency criterion. But, as with deposit insurance, the fly in this ointment is that situations rife with inefficiency may be inherited by a policymaker precisely because of his inability to commit to allowing inefficiency after the fact. AIG, for its part, may have anticipated (correctly) that the circumstances in which the credits they insured would fail would likely also be ones in which aggregate economic activity was already significantly affected. In turn, in these situations, the firm may have expected assistance from a policymaker - especially one concerned with ex-post efficiency. As a result, such views may have been important in allowing AIG and others perceived to be TBTF to grow and create systemic risk.

It is also important to recognize that the ex-ante standard is not an automatic call for pure laissez faire. For example, the institution of deposit insurance for banking can be provided by the public and, in turn, can help ensure that the banking system is productive from the ex-ante viewpoint. Similarly, in the context of the example describing the time-inconsistency problem, an ex-ante standard would differentiate sharply between the two following scenarios. First, in the example given, the risks of building on the floodplain were high enough to make investment there a poor choice. Moreover, no houses had yet been built. Therefore, in this instance, the inability of a policymaker to commit to 
avoiding a bailout led directly to wasteful investments that necessitated bailouts. Consider now a modification of this scenario where the land floods infrequently enough to attract private investors even in the absence of any possible bailout. However, assume that insurance markets for some reason don't function well. In this case, would-be homeowners face risks, but because they cannot insure against them, may fail to build even though it is productive to do so from an ex-ante standpoint. Now, imagine that the government offers insurance to those building there and charges actuarially fair premiums. This will improve ex-ante efficiency, as citizens will now be able to pool their risks with others. And in the rare event that a flood does occur, the policymaker will make payments to help people rebuild. This example suggests that a crucial litmus test for useful ex-post interventions is whether or not they can reasonably be interpreted as proxying for a missing market.

A more general danger (i.e., one that is not restricted to financial market policy) in abandoning the ex-ante efficiency standard for policymaking is that it opens the door, in principle, to the implementation of policies that merely redistribute. However, redistributionary policies are not appropriately conducted by the regulators of financial institutions who can act fairly unilaterally. Rather, such actions are more appropriately conducted through the consensus building inherent in the legislative system. Politically appointed decisionmakers, especially those whose choices are not immediately subject to open debate or transparent appropriations processes, may find themselves under intense pressure to pursue such policies. Moreover, given the speed with which interventions in financial institutions have taken place, there will be incentives for the owners, creditors, and employees of a handful of financial firms to invoke the specter of systemic risk to request interventions that are primarily transfers.

The preceding arguments suggest that ex-post interventions carried out in the name of mitigating systemic risk may themselves pose a risk to the welfare of the citizenry. To avoid this, the public must ask regulatory authorities to consistently articulate the pure ex-ante efficiency rationale for their proposed actions. Moreover, such a defense of intervention must spell out precisely why private contracting, even when it raises the possibility of ex-post inefficiency, may not simply reflect the best that society can achieve ex ante to deal with various informational- and commitment-related impediments. Federal Reserve Bank of Richmond President Jeffrey Lacker has expressed this view fairly strongly. ${ }^{25}$ As mentioned at the outset, economic theory does

\footnotetext{
${ }^{25}$ Lacker (1998).
} 
offer guidance here. The presence of widespread market power arising from barriers to entry and the inability to trade certain contracts due to various spatial or informational frictions are two of the most obvious impediments to achieving ex-ante efficiency. And in the context of financial intermediation, theoretical work on the effects of various impediments to trading arrangements such as collateral scarcity, maturity mismatch, and centralized netting are all ongoing. We have also briefly alluded to the inability of the government to commit against bailout as an influence on ex-ante financial contracting, and thereby fragility and real outcomes. ${ }^{26}$

One explanation that has been widely circulated to account for the severity of the crisis, and especially its transmission to the real economy, is that there was a dramatic expansion of the set of financial institutions with balance sheets that featured a large maturity mismatch. That is, in the recent crisis there was an expansion ${ }^{27}$ in the set of financial actors that used short-term debt to invest in long-term assets such as real estate or collateralized debt obligations with underlying value dependent on long-maturity loans such as mortgages. The expansion of such entities in the run-up to the collapse of real estate prices has been called the rise of a "shadow" banking system. The Diamond and Dybvig account of banking suggests that if such an expansion is not met with (i) a concomitant expansion of something analogous to deposit insurance and (ii) publicly imposed limits on risk-taking via capital requirements or portfolio restrictions, fragility and misallocation are likely to ensue.

By all accounts, strict leverage limits and capital requirements were not measures imposed on hedge funds, investment banks, and money market mutual funds, which all constructed balance sheets that predisposed them to the sort of instability discussed above. Therefore, one implication may be to work to recognize, in real time, those financial institutions that have balance sheets with bank-like characteristics but that are not being treated accordingly.

Before becoming overly optimistic about being just one more regulation away from containing systemic risk, however, it is useful to ask why such maturity transformation took place outside of insured and regulated depository institutions. There is good reason to think that it was precisely to escape the regulation facing the latter. Therefore, unless we are confident that we can detect maturity transformation in all its forms, our best bet may be to allow creditors of unregulated institutions to bear risk, especially of the macroeconomic kind. This

\footnotetext{
${ }^{26}$ See Chari and Kehoe (2010) for a formal analysis of this idea.

27 See, e.g., Acharya et al. (2009) for details.
} 
may only be possible via credible promises to allow such entities to fail. In other words, the additional costs of monitoring and regulating may well outweigh any additional benefits of creating yet more actors in the officially insured maturity transformation business.

\section{The Variety of Linkages and Reasons for Spillovers Will Make Regulating Hard}

We argued above that not only are there many ways for financial sector entities to be linked and create inefficiency in the wake of shocks, but also that many contractual choices that create ex-post inefficiency were deliberately aimed at allowing for gains from trade between two parties. Recalling the example of mortgage lenders committed to foreclosing on late payers, we saw that even though debt forgiveness would be ideal after the fact, such a policy would be ruinous for lenders, and thus ultimately choke off credit to borrowers.

From a policy perspective, this suggests that it may be beneficial to tie the hands of policymakers in the wake of crisis: It is perhaps the only way to give participants, especially nonbanks, the incentives to avoid becoming overly linked with each other and choosing balance sheets that make them fragile. But here again, a policy of never intervening may not always be desirable either. As Diamond and Dybvig's analysis shows, the presence of fragility sometimes comes from the achievement of other, more desirable objectives as well, and in these cases programs like deposit insurance can indeed help achieve ex-ante efficiency.

Another problem facing would-be systemic risk regulators is that asset price collapses often seem to precede financial crises. In the recent crisis, the collapse in housing prices has been widely seen as a crucial starting point for events. In particular, many of the mortgage contracts that required little or nothing from the borrower for more than a year, only to ask for far more in subsequent periods, were predicated on increases in house prices that were ultimately not realized. Any regulator charged with mitigating systemic risk would have had to take a position on the likely path of house prices. Such forecasts are not easy to make. In fact, from a theoretical perspective, forecasting the path of the price of any asset, especially when markets are functioning well, is inherently difficult. Moreover, in addition to forecasting house prices, assessing the implications of changes in these prices for various market participants would have required detailed knowledge of not only mortgage contracts, but also the health of all those who acquired exposure to them.

Lastly, it should be kept in mind that in some cases, the very regulations intended to protect the public from excessive risk-taking may 
have unintended consequences. As discussed earlier, FVA may have played a decisive role in exacerbating the initial effects of the financial crisis, even though it was instituted to prevent the public from being exploited by financial intermediaries with access to backstop public funding and insurance. As a result, it is difficult to know what a policymaker intent on limiting systemic risk might have done differently. The preceding ideas lead to the question of how much discretion policymakers (ought to) have. We will argue that the answer may be: not much.

\section{Broader Powers Are not Necessarily Better}

The perception that disastrous outcomes would have occurred in the absence of timely intervention by policymakers has now led to calls to endow regulatory bodies, including the Federal Reserve System, with wider powers. Such efforts may have benefits, but they also carry risks. The benefits of having such a regulator, especially when it is the Fed, are listed frequently, ${ }^{28}$ so we will focus on some of the risks. ${ }^{29}$ First, recall that the time inconsistency problem arises not in spite of, but rather because a policymaker is benevolent, seeking at each moment only to do what is best for the public. And yet, it is this inability to stick to a rule that created the very conditions that led such a policymaker to have to act: One need not have a jaundiced view of policymakers to worry about giving them discretion.

With respect to the discretion possessed by policymakers, a central question that at present does not have a clear answer is whether policymakers can ever have commitment to not revisit their policy announcements. One view is that the answer is no; policymakers will always reoptimize and refuse to allow very bad things to occur. The dramatic policy responses by the Fed and the executive branch of government suggest that they indeed reoptimized, seeking to improve outcomes from the present moment forward. However, what is less clear is the extent to which the preconditions for a crisis would have occurred in a world where policymakers were determined to always let the chips fall where they may. If one's view is that policymakers do not have commitment to avoiding bailouts, then it follows that they must limit behavior that would force their hand in the wake of any shock, especially a large one. This is the essence of the argument for

\footnotetext{
28 See, e.g., Labonte (2009).

${ }^{29}$ To be clear, what is being emphasized is that there are some risks that would face any systemic risk regulator. The question of who that regulator should be (e.g., the Fed, the Office of Thrift Supervision, etc.) is a separate issue- one that we do not address here.
} 
preventing firms from growing TBTF, especially when they do so by issuing debt.

If one's view is that policymakers are unable to tolerate ex-post inefficiency, then the source of this inability matters. In particular, if policymakers pursue bailouts because they fear a public unwilling to brook such outcomes, it becomes crucial that the public understands the extent to which a given after-the-fact intervention sows the seeds for behavior that will create the next crisis. And here, the received science is not definitive. Large banks and other financial institutions $d o$ provide potential efficiency gains through scale and network effects. Nonetheless, if TBTF is known to influence some banks' and financial intermediaries' decisions, economic theory tells us that they will certainly choose too much risk if left to their own devices. As a result, allowing for very large, complex, and interconnected institutions means vigilance by policymakers and regulators. It is not obvious, though, that very pervasive regulation can be successful, especially since it creates the distinct possibility of regulatory capture whereby policymakers subtly become beholden to the entity they are charged with regulating. Future work must help delineate clearly the gains the public gets from allowing financial intermediation to grow extremely concentrated and the gains from allowing nonbanks to hold bank-like balance sheets with heavy short-term leverage and long-term assets.

How relevant was TBTF in recent events? An emerging view is that the risk and size assumed by banks was quite deliberate and quantitatively large enough to severely constrain subsequent lending by banks in the wake of losses due to mortgage default. As Richardson and Acharya, Schnabl, and Suarez document, ${ }^{30}$ banks were "playing the leverage game" and thereby creating a serious TBTF problem. The reason that even securitized loans sold into conduits threatened bank balance sheets is that banks were obligated to provide credit support in the event that the assets performed poorly. ${ }^{31}$ As a quantitative matter, the reductions in value of the securities held by conduits were enough to wipe out the capital of many institutions that had issued support agreements. As a result, the securitization, which would have worked well if the assets had been sold, did not ultimately transfer risk away from banks and toward investors. Similarly, the credit support that many of the issuers of real-estate- backed commercial paper (e.g., SIVs and conduits) had from banks ensured that their creditors would not see losses. Nonetheless, the willingness of banks to issue such commitments may well have been affected by the view that they were TBTF.

\footnotetext{
${ }^{30}$ Richardson (2009) and Acharya, Schnabl, and Suarez (2010).

${ }^{31}$ See, e.g., Acharya and Schnabl (2009).
} 
As a result, such commitments may have served as a way to transfer risk originating in a SIV to the taxpayer by way of the banking system. In this view, the fundamental problem is not the credit lines but the inability of the policymaker to credibly commit to allowing an overextended institution to simply fail.

\section{CONCLUDING REMARKS}

We have identified systemic risk with linkages between market participants that lead to outcomes that can be unambiguously improved after a shock. As to the sources of such outcomes within financial markets, certain contractual arrangements featuring inflexibility, or requiring collateral infusions or liquidations in the event of a negative shock, appear important. However, we have also argued that in many cases, the trading arrangements that display such features may themselves have been constructed precisely to deal efficiently with problems of asymmetric information and limited commitment between trading partners. Moreover, in some instances, contractual arrangements may have been constructed with a view to exploit the unwillingness of benevolent policymakers to allow certain financial market entities to be liquidated. As a result, we have argued that the right goal for policymakers is to do as much as possible to ensure that the institutional arrangements for trade can attain efficiency as viewed before the arrival of shocks. The successful pursuit of this objective may then require credible commitments to withhold assistance in the wake of a shock. Understanding the channels by which after-the-fact interventions alter, and perhaps destroy, the ability of society to allocate resources productively is of critical importance. It is particularly crucial for measuring the longrun costs of the discretionary policymaking that is currently taking place. In the context of fiscal and monetary policy, there is now something of a consensus among economists that discretion is harmful. The consequences of discretion in financial markets are now getting more attention as well. In the interim, the broader public should remain realistic about the benefits of codifying and dealing with systemic risk. In addition, society must remain vigilant to ensure that systemic risk is not invoked to further ends unrelated to the long-run realization of gains from trade. 


\section{REFERENCES}

Acharya, Viral V., and Matthew Richardson, eds. 2009. Restoring Financial Stability: How to Repair a Failed System. Hoboken, N.J.: John Wiley.

Acharya, Viral V., and Phillip Schnabl. 2009. "How Banks Played the Leverage Game." In Restoring Financial Stability: How to Repair a Failed System, edited by V. Acharya and M. Richardson. Hoboken, N.J.: John Wiley, 83-100.

Acharya, Viral V., Lasse Pedersen, Thomas Philippon, and Matthew Richardson. 2009. "Regulating Systemic Risk." In Restoring Financial Stability: How to Repair a Failed System, edited by V. Acharya and M. Richardson. Hoboken, N.J.: John Wiley, 283-303.

Acharya, Viral V., Phillip Schnabl, and Gustavo Suarez. 2010. "Securitization without Risk Transfer." Cambridge, Mass.: National Bureau of Economic Research Working Paper 15730 (February).

Aguiar, Mark, and Erik Hurst. 2005. "Consumption versus Expenditure." Journal of Political Economy 113 (5): 919-48.

Blundell, Richard, Luigi Pistaferri, and Ian Preston. 2008. "Consumption Inequality and Partial Insurance." American Economic Review 98 (5): 1,887-921.

Brunnermeier, Markus K. 2009. "Deciphering the Liquidity and Credit Crunch 2007-2008." Journal of Economic Perspectives 23 (1): $77-100$.

Cecchetti, Stephen G. 2009. "Crisis and Responses: The Federal Reserve in the Early Stages of the Financial Crisis." Journal of Economic Perspectives 23 (1):51-76.

Chari, V.V., and Patrick J. Kehoe. 2010. "Bailouts, Time Inconsistency, and Optimal Regulation." Federal Reserve Bank of Minneapolis Research Department Staff Report (February).

de Bandt, Olivier, and Philipp Hartmann. 2000. "Systemic Risk: A Survey." European Central Bank Working Paper 35 (November).

Debreu, Gerard. 1959. Theory of Value: An Axiomatic Analysis of Economic Equilibrium. New Haven, Conn.: Yale University Press.

Diamond, Douglas W., and Philip H. Dybvig. 1983. "Bank Runs, Deposit Insurance, and Liquidity." Journal of Political Economy 91 (3): 401-19. 
Geithner, Timothy. 2009. Testimony before the House Financial Services Committee, Washington, D.C. (March 24).

Heathcote, Jonathan, Kjetil Storesletten, and Giovanni Violante. 2005. "Two Views of Inequality over the Life Cycle." Journal of the European Economic Association 3 (3): 765-75.

Kiyotaki, Nobuhiro, and John Moore. 1997. "Credit Chains." Princeton University, mimeo (January).

Kydland, Finn E., and Edward C. Prescott. 1977. "Rules Rather Than Discretion: The Inconsistency of Optimal Plans." Journal of Political Economy 85 (3): 473-91.

Labonte, Marc. 2009. "Systemic Risk and the Federal Reserve." Washington, D.C.: Congressional Research Service (October 28).

Lacker, Jeffrey M. 1998. "On Systemic Risk." Comments presented at the Second Joint Central Bank Research Conference on Risk Measurement and Systemic Risk at the Bank of Japan, Tokyo (November 16-17).

Paulson, Henry. 2008. Testimony before the House Committee on Financial Services, Washington, D.C. (November 18).

Richardson, Matthew. 2009. "Causes of the Financial Crisis of 2007-2009." In Restoring Financial Stability: How to Repair a Failed System, edited by V. Acharya and M. Richardson. Hoboken, N.J.: John Wiley, 57-60.

Scholz, John Karl, Ananth Seshadri, and Surachai Khitatrakun. 2006. "Are Americans Saving 'Optimally' for Retirement?" Journal of Political Economy 114 (4): 607-43.

Shleifer, Andrei, and Robert W. Vishny. 1992. "Liquidation Values and Debt Capacity: A Market Equilibrium Approach." Journal of Finance 47 (4): 1,343-66.

Stern, Gary H., and Ron J. Feldman. 2004. Too Big to Fail: The Hazards of Bank Bailouts. Washington, D.C.: Brookings Institution Press.

Townsend, Robert. 1979. "Optimal Contracts and Competitive Markets with Costly State Verification." Journal of Economic Theory 21 (2): 265-93. 